\title{
Plasma progesterone changes and length of oestrous cycle in Rusa Deer (Rusa timorensis)
}

\begin{abstract}
A study was conducted to profile the plasma progesterone (P4) concentrations and establish the length of oestrous cycle in the Rusa timorensis during the breeding season. Five healthy hinds were selected for peripheral blood sampling twice weekly to gauge the P4 levels by radioimmunoassay, at the start of the breeding season indicated by rutting behaviours of sexually active males. The hinds were polyestrous as proven by the cyclic trend of P4 levels. After the presumptive oestrus indicated by the lowest P4 concentrations $(0.20 \pm 0.09 \mathrm{ng} / \mathrm{ml})$, this ovarian hormone was markedly elevated on day 7 of the cycle $(0.78 \pm 0.20 \mathrm{ng} / \mathrm{ml})$, reached its peak $(2.61 \pm 0.23 \mathrm{ng} / \mathrm{ml}, \mathrm{P}<0.05)$ on day 14 , and then declined to the basal level in the subsequent oestrus. The mean oestrous cycle length in $\mathrm{R}$. timorensis during the breeding season was 19.2 days with a range of 18-21 days, and the pattern of circulating progesterone during the oestrous cycle of the R. timorensis is similar to those of other deer species. It was also observed that the length of oestrous cycle of $\mathrm{R}$. timorensis determined by gauging the progesterone levels and observation of the oestrous behaviours as well as changes in the cellular pattern of vaginal epithelial cells are highly consistent.
\end{abstract}

Keyword: Rusa timorensis; Progesterone; Estrus cycle; Rusa deer 